\title{
Debt-Management Policy and the Own Price Elasticity of Demand for U.S. Government Notes and Bonds
}

\author{
RICHARD W. LANG and ROBERT H. RASCHE
}

D

EBT-management policies of the U.S. Govemment are actions which affect the composition of the publicly held Federal debt. Such actions include operations of both the U.S. Treasury and the Federal Reserve. As a macroeconomic policy tool, discretionary debt-management policy attempts to affect economic activity in a specific way by altering the maturity structure of the Government's debt. The effectiveness of such a policy depends upon the extent to which changes in the composition of the debt affect the structure of interest rates, and the extent to which changes in the structure of interest rates affect economic activity.

The effectiveness of discretionary debtmanagement policy has been debated for a long time, both on a theoretical and an empirical level. A major attempt at discretionary debtmanagement policy, called "Operation Twist," occurred in the early 1960s. The Treasury, in coordination with the Federal Reserve, attempted to twist the structure of interest rates in order to lower longutem interest rates to promote investment and economic growth, while raising shortterm rates to improve the balance-of-payments deficit. Empirical studies of "Operation Twist" have not conclusively determined whether such debt-management policies are effective. ${ }^{1}$

\footnotetext{
1See, for example, Franco Modigliani and Richard Sutch, "Innovations in Interest Rate Policy," The American Economic Review (May 1966), pp. 178-97.
}

On the theoretical level, there are two major ap proaches to the term structure of interest rates which have conflicting implications for the effectiveness of debt-management policy. The pure expectations theory implies that debt-management operations have no lasting impact on the structure of interest rates. The preferred-habitat theory, on the other hand, implies that changes in the quantity of short-term relative to long-term debt can have significant effects on the term structure of interest rates." A large amount of empirical work on both theories has accumulated, but with inconclusive results. At the present time, the preferred-habitat theory cannot be rejected, so that it is not clear whether changes in the relative quantities of debt affect the structure of interest rates. However, if such effects exist, their magnitude may be quite small.

This paper investigates the effect of debt-management operations on the structure of interest rates. It is shown that even if the maturity structure of the debt

David Meiseman, The Term Stucture of Interest Rates (Fnglewood Cliffs, N. J.: Prentice-Hall, Inc., 1962); Burton Gordon Malkiel, The Term Structure of Inferest Rates: Expectations and Behavior Patterns (Princeton: Princeton University Press, $1966^{\circ}$.

3Modigtiani and Sutch, "Innovations in Interest Rate Policy," and "Debt Manayement and the Term Structure of Interest Rates: An Empirical Analysis," The Joumal of Political Economy (Augest 1967), pp. 569-89; Charles R. Nelson, The Term Structure of Interest Rates (New York: Basic Books, Inc., 1972). 
is admitted as a variable which affects the structure of interest rates, there are reasons to expect that such an effect is small. This conclusion helps to explain the inability of researchers to identify empirically such debt-management effects on the term structure of interest rates. It also implies that only massive changes in the composition of the debt could significantly alter the differential between long- and shortterm interest rates.

To derive these results, demand curves for shortand longuterm debt are used to formulate a termstructure equation similar to that of other researchers. This equation relates the long-term rate to the shortterm rate, expected future short-term rates, and the stocks of short- and long-term debt. In this framework, the effects of the debt variables on the longterm rate depend upon the elasticity of demand for long-term debt. The own price elasticities of demand for forty-seven Treasury issues marketed between 1952 and 1976 are measured, and the demands for both short- and longuterm securities are found to be very elastic. These large elasticities of demand imply that debt-management operations have little effect on the term structure of interest rates.

\section{算墨基

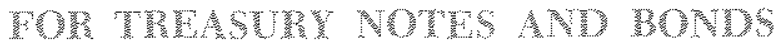

It is relatively easy to measure the own price elasticity of demand for a commodity in introductory economics courses. Two points on the demand curve are chosen, and then a simple formula is used to obtain the price elasticity. However, in actual empirical work this technique is generally not operational, and a more involved approach must be employed. Both demand and supply functions for the commodity must be appropriately specified, time series data on the relevant variables must be collected, and simultaneous equation estimation techniques must be employed that control for the variables that shift the demand and supply curves. Using this approach, the measurement of the own price elasticity of demand for a financial asset is especially difficult because of the problems of specifying the asset's supply curve, and because of high correlations among prices of altemative assets.

The simpler method of using two points on an asset's demand curve can be employed, however, in

\footnotetext{
4 See Modigliant and Sutch, "Innovations in Interest Mate Policy," and "Debt Management and the Term Structure of Interest Rates."
}

the measurement of the own price elasticity of demand for U.S. Treastry notes and bonds. This approach is made possible by the Treasury's past use of the "subscription sale" technique for marketing such securities.

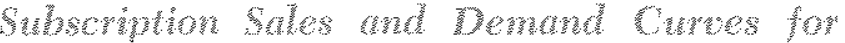

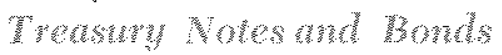

Prior to November 1970 , and on three occasions during 1976, the U.S. Treasury sold Treasury notes and bonds on a subscription basis, in contrast to the auction method that is used for Treasury bills. ${ }^{5}$ When the Treasury offers debt issues on a subscription basis, it annomces the maturity date, coupon rate, and price at which it will issue debt, and invites tenders for the issue." The Treasury also announces the approximate amomt of debt which it plans to issue as a result of the subscription sale. In the event that the volume of tenders is greater than the amount of debt which the Treasury wishes to sell, subscriptions are filled on a partial basis known as allotments. The allotment procedures, which have varied frequently from issue to issue, are published in the amouncement of the offer. ing. However, the fraction of the order which will be

This auction method has also been used in marketing Treasury notes and bonds since November 1970 , with the exception of the three issues in 1976.

"For example, in April 1976, the "Treasury announced: "The Deparment of the Treasury will offer to sell $\$ 3.5$ billion of 10-year notes as one of three securities to be issued for the purpose of refurding debt maturing May 15 and raising new cash. The anount of the offering may be increased by a reasonable amount to the extent that the total amount of subscriptions for $\$ 500,000$ or less accompanied by $20 \%$ deposit so warrants. ."

"The notes now being offered will be $7 \%$ \% Treasury Notes of Series A-1986 dated May 17, 1976, due May 15, 1986 (Cusip No. 912827 FP 2). They will be sold at par. interest will be payable on a semianulal basis on November 15, 1976, and thereafter on Nay 15 and November 15. ."

"Subscriptions will be received through Wednesday, May 5, 1976, at any Federal Reserve Bank or Branch and at the Bureat of the Public Debt, Washington, D. C. 20226 ; provided however, that subscriptions up to $\$ 500,000$ accompanied by a $20 \%$ deposit will be considered timely receved if they are mailed to any such agency under a postmark no later than T"uesday, May 4, 1976...'

"The Secretary of the rreasury expressly reserves the right to accept or reject any or all subscriptions, in whole or in part, and his action in any such respect shall be final. Subject to these reservations, subseriptions for $\$ 500,000$, or less, will be allotted in full provided that $20 \%$ of the face value of the securities for each subscriber is submitted as a deposit.

"Subscriptions not accompanied by the $20 \%$ deposit will be received subiect to a percentage allotment irrespective of the size of the stabscription. No allotmext will be made of these subseriptions until and mless the subscriptions acompanied by $20 \%$ deposit purswant to the preceding paragraph have been allotted in full. . . 
filled, the allotment ratio, is not known until after all offers to buy have been submitted.

Subscription sales of Government securities offer a unique opportunity to observe two points on the market demand curve for the particular security being offered. First, the Treasury announces a price, usually par, and invites the private sector to make offers for the amount that they wish to purchase at that price ( $P_{\mathrm{s}}$ in Figure 1 ). Once the volume of subscriptions has been counted, a point on the demand curve, such as A in Figure I, can be located. After the subscription books are closed, but before the date of issue of the security, the Treasury announces allotment fractions and the total amount of the security which will be issued, represented by $Q_{i}$ in Figure $I$. When the quantity which the Treasury issues is less than the amount of subscriptions submitted, the issue is said to have been oversubscribed. Once the amount to be issued has been determined by the Treasury, a second point on the demand curve for this issue can be observed. This point is determined by the amount issued and the price at which the issue sells in the Govermment securities market, $\mathrm{P}_{\mathrm{m}}$ in Figure $\mathrm{I}^{\mathrm{T}}$

These two points can be safely regarded as approximations to two points on the same demand curve. First, the time which elapses from the close of the

It might be argued that the quantity $Q_{8}$, associated with point $A$ in Figure $I$, is an overestimate of the true quantity demanded at the announced price, on the grounds that the economie units which submit bids which are subject to partial allocation inflate those bids based on their expectations of the allocation ratio (the percent of their bid which will be filled). The allocation ratio has been quite variable from isstue to issue, ranging from a low of 5 percent to a high of 70 percent. The mean of the allocation ratios is 27.4 percent and the standard deviation is 17.2 percent. Thus, it would seem to be quite difficult to guess the allocation ratio on any particular issue with great confidence.

It might also be argued that $Q_{s}$ is an overestimate of the true quantity demanded at price $P_{s}$ on the grounds that market participants submit bids with the expectation that $P_{m}$ exceeds $P_{s}$. Thus, $Q_{s}$ includes some speculative demand by traders who, knowing the prices of outstanding securities which are close substitutes and knowing (or knowing approximately) the amount to be issued, inflate their bids with the intention of purchasing for resale. According to this argument, the larger the expected price differential, $P_{m}-P_{s}$, the larger would be the quantity differential, $Q_{5}-Q_{\mathrm{i}}$. However, such behavior, although possible, does not apparently characterize a large portion of the demand by market participants for these issues. Using the data in Tables $I$ and If, with $P_{m}$ the price on the first day of trading, the simple correlation between $\mathrm{P}_{\mathrm{m}}-\mathrm{P}_{\mathrm{s}}$ and $Q_{s}-Q_{i}$ is very low $(0.19)$, as is the simple correlation between the percentage price change and the percentage quantity change $(0.08)$. (This assumes, of course, that market traders expect the market price to be $\mathrm{p}_{m}$. Considering that information on close substitutes is readily available, this assumption does not seem overly tentions.) Consequently, even though there may be some speculative demand for these issues at price $P_{s}$ which leads to $Q_{s}$ being an overestimate of the true quantity demanded, the above correlations indicate that the problem is not very severe. In this regard, see foot" note 15 below.

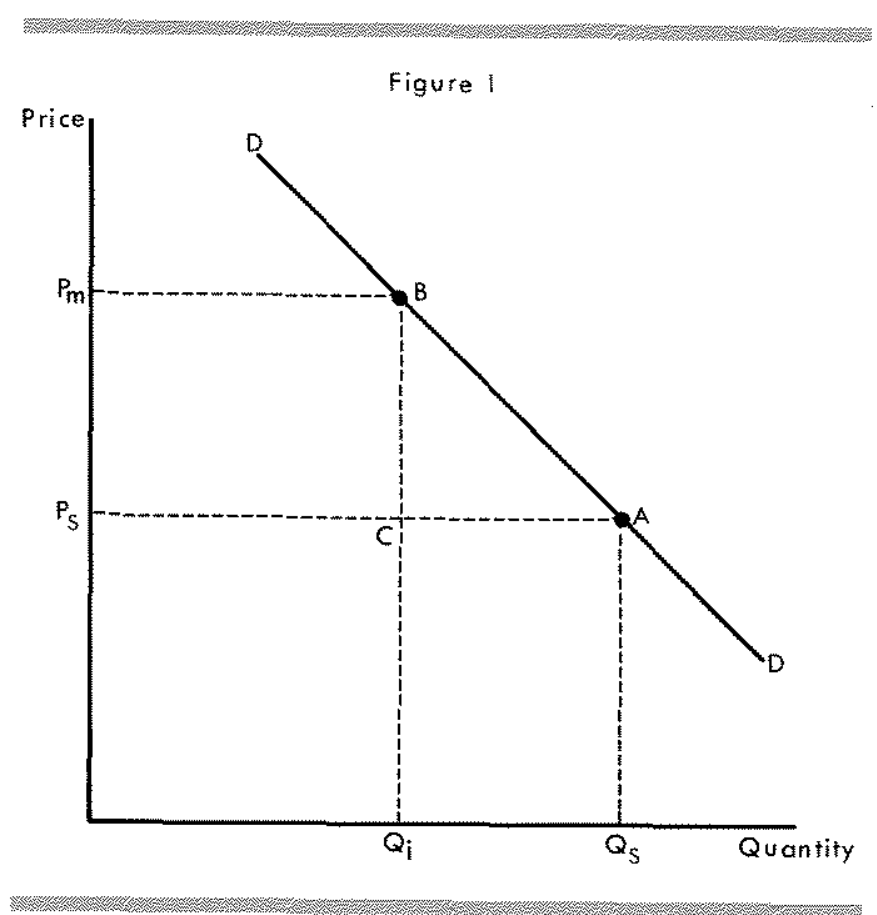

subscription books to the date of issue of the security is quite short. ${ }^{8}$ Second, the securities are usually traded by Government securities dealers in the intervening period on a 'when issued' basis once the allocation has become known. Therefore, very little information that would shift the demand curve for the particular issue would become available between the time the volume of subscriptions, $Q_{\mathrm{s}}$, is submitted and the time the market price, $P_{m}$, for the issued volume, $Q_{i}$, is observed. Third, small shifts in the demand curve would result in only small changes in the position or shape of the demand curve, so that various measures of points $A$ and $B$ in Figure $I$ are still close approximations of two points on the same

\footnotetext{
8In the case of the 10 year note issued in May 1976, which is eited in footnote 6 , the subscription books closed on May 5 , 1976 and the security was issued on May 17, 1976. Only eight trading days elapsed between these two dates. This is a typical lag for subscriptions issued since the 19505.

The possibility of the demand curve being shifted because of monetary policy actions which affect short-term rates is minimized because of the 'even-keel' commitment. ". . . evenkeel has meant that, for a period encompassing the announcement and settlement dates of a large new security offering or refunding by the Treasury, the Federal Reserve has not made new monetary policy decisions (as contained in annomcenents from the Board of Governors or as specified in the second paragraph of the policy directives of the Federal Open Market Committee) that would impede the orderly marketing of Treasury securities and significantly increase risks of market disuuption from sharp changes in market attitudes in the course of a financing." Stephen H. Axilrod, "The FOMC Directive as Structured in the Late 1960"s: Theory and Appraisal," in Open Market Policies and Operating Procedures - Staff Studies, Board of Governors of the Federal Reserve System (July 1971), p. 28 .
} 
demand curve. Thus, we can assume, without danger of large measurement error, that points $A$ and $B$ in Figure I approximate two points on the same demand curve.

Data have been obtained from various issues of the Treasury Bulletin on fifty-one subscription issues which were offered during the period from June 1952 through August 1976. Issues exchanged exclusively in advance refunding operations - not exchanged for cash - were excluded from the sample. ${ }^{10}$ Two issues which were auctioned in 1963 were also excluded. Data for the fifty-one issues are given in Table I, including the offering date, maturity date, coupon, term-to-maturity, offering price by the Treasury $\left(\mathbf{P}_{\mathrm{s}}\right)$, volume of subscriptions tendered $\left(Q_{s}\right.$ - excluding subscriptions tendered by Government trust accounts and the Federal Reserve System), and the volume of subscriptions filled $\left(Q_{1}\right)$. All of these issues were oversubscribed.

The additional data which is required to calculate the price elasticity of demand for each security is the market price, $\mathrm{P}_{\mathrm{m}}$. Data which were ased to construct measures of this variable were obtained from closing quotations published daily in The New York Times. Table II contains daily market quotations from the first quotation subsequent to the opening of the subscription books, through the date of issue of the security. ${ }^{11}$ From these, four measures of the market price quotation were constructed: 1) the market price on the first day of trading subsequent to the opening of the subscription books $\left.\left(\mathbf{P}_{x}\right) ; 2\right)$ the average of the prices on the first five days of trading $\left(\mathrm{P}_{2}\right) ; 3$ ) the average of the prices of all trading days from the first day of trading through the day of issue $\left(P_{3}\right)$; and 4) the market price on the day of issue $\left(P_{4}\right)$.

These prices can be compared with the issue prices set by the Treasury. There are only four cases in which the market price fails to rise above the Treasury issue price using at least one of the four measures of the market price..$^{12}$ For these four issties, no

\footnotetext{
9In fact, various measures of the price, $\mathbf{p}_{\mathrm{m}}$, associated with point $B$ are used in the analysis below without substantively affecting our conclusions.

${ }^{10} \mathrm{Advance}$ refunding consists of offering holders of an existing security the option of exchanging it, prior ta its maturity, for a newly issued security.

11The market quotations as published in The New York Times give fractional prices in $32 \mathrm{nds}$ of a point. In Table II the price quotations have been converted to a decimal basis and rounded to the second decimal place.

12In Table II, these issues are those for which the subscription books opened on: $1 / 12 / 59,4 / 04 / 60,10 / 30 / 67 b$, and $5 / 08 / 68$
}

meaningful negatively sloped demand curve can be constructed. Thus, our sample is reduced to fortyseven issues for which a negatively sloped demand curve was observed using at least one of the four measures of market price.

Given two points on a demand curve, the appropriate measure of the price elasticity, $\varepsilon(Q, P)$, depends on the functional form assumed for the demand curve. In elementary texts, where the emphasis is on linear demand curves, the distinction is frequently made between are and point elasticities, and several formulas are typically suggested for computing arc elasticities. ${ }^{13}$ If the demand curve is log-linear, then it is appropriate to construct the arc elasticity estimate as the ratio of the difference of the logarithms of the two quantities to the difference of the logarithms of the two prices, since the elasticity is constant along the entire range of the demand curve.

An alternative case, which is of interest in the later discussion of the term structure of interest rates, is a semi-logarithmic demand curve, in which the logarithm of the quantity demanded is a function of the level of the price or interest rate. In this case, it is appropriate to compute the arc elasticity as the ratio of the difference in the logarithms of the two quantities to the percentage change in the price or interest rate, where the latter can be measured in the various ways typically suggested for a linear demand function. In our sample, however, the differences in the two price or interest rate observations are so small that insignificant measurement errors are introduced in the semi-logarithmic case if the elasticity is measured by the ratio of the difference of the logarithms of the quantities to the difference of the logarithms of the prices. ${ }^{14}$

Table III contains the measured price and interest rate elasticities (in absolute values) for each of the securities in the sample, based on the four measures of the market price and the corresponding yields to maturity. The securities have been arranged in order of increasing maturity rather than by date of issue, so that the elasticities of issues with similar maturities can be compared.

1:For four alternative formulas for computing are elasticities with Inear demand curves see, Kenneth E. Boulding, Economic Analysis: Microeconomics, 4th ed. (New York: Harper \& Row, I966), p. 194.

14. Using the notation of Figure I:

$$
\begin{aligned}
\varepsilon(\mathrm{Q}, \mathrm{P}) & =\frac{\mathrm{dQ} P}{\mathrm{Q}} \frac{\mathrm{d} P}{\mathrm{~d}}=\frac{\mathrm{d} \ln \mathrm{Q}}{\mathrm{d} \ln \mathrm{P}} \\
& =\frac{\ln \mathrm{Q}_{\mathrm{s}}-\ln \mathrm{Qi}}{\ln \mathrm{P}_{\mathrm{s}}-\ln \mathrm{P}_{\mathrm{Rn}}}
\end{aligned}
$$


Toble 1

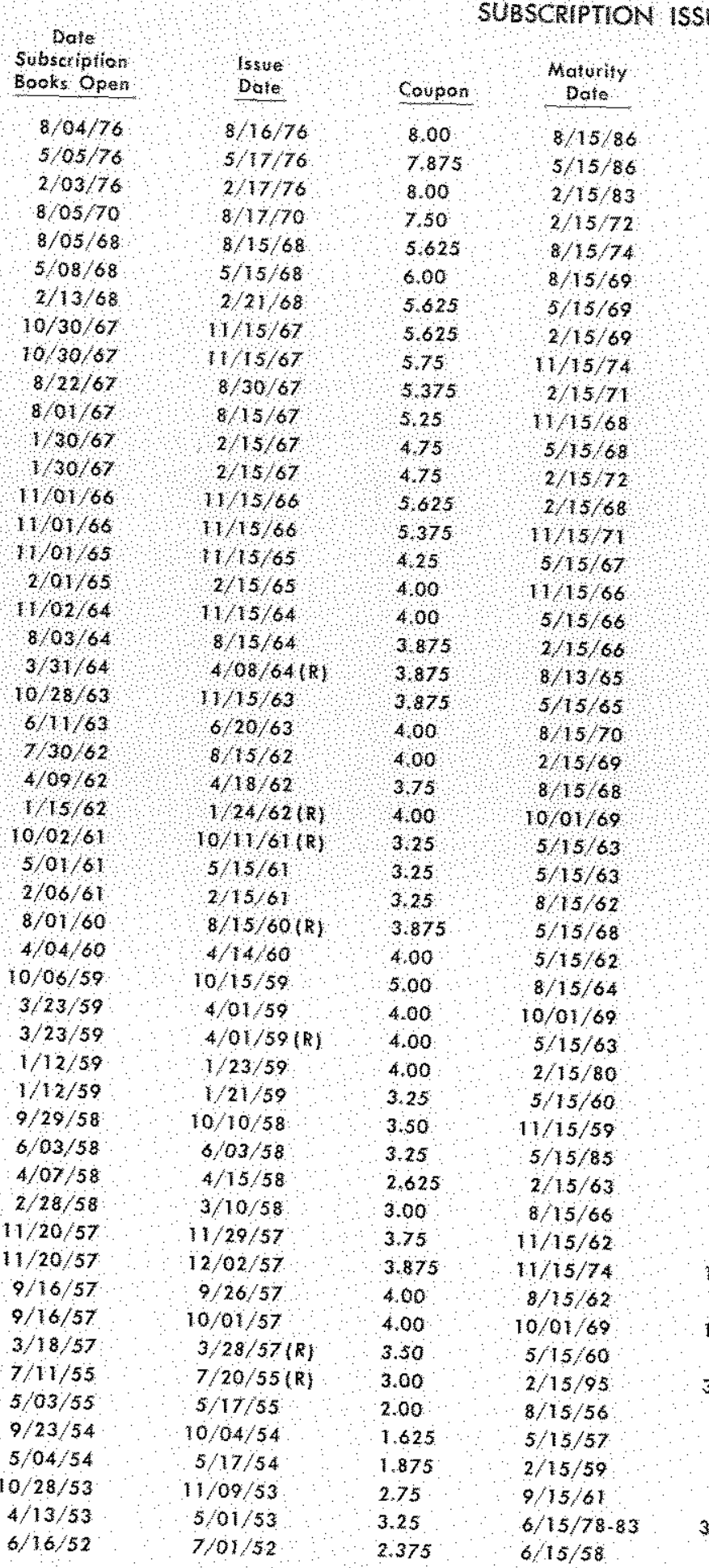

$(\mathrm{R})=$ Reopened issue

* Millioris of dollats

Sonce: Table pDO+ "Offerings of public Marketable Securties other than Weeky Treasury balls, and Table

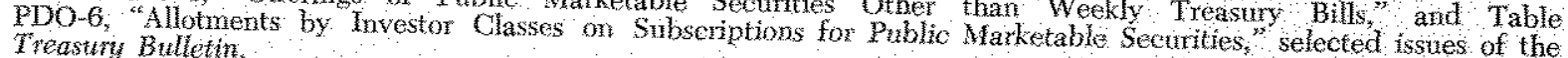




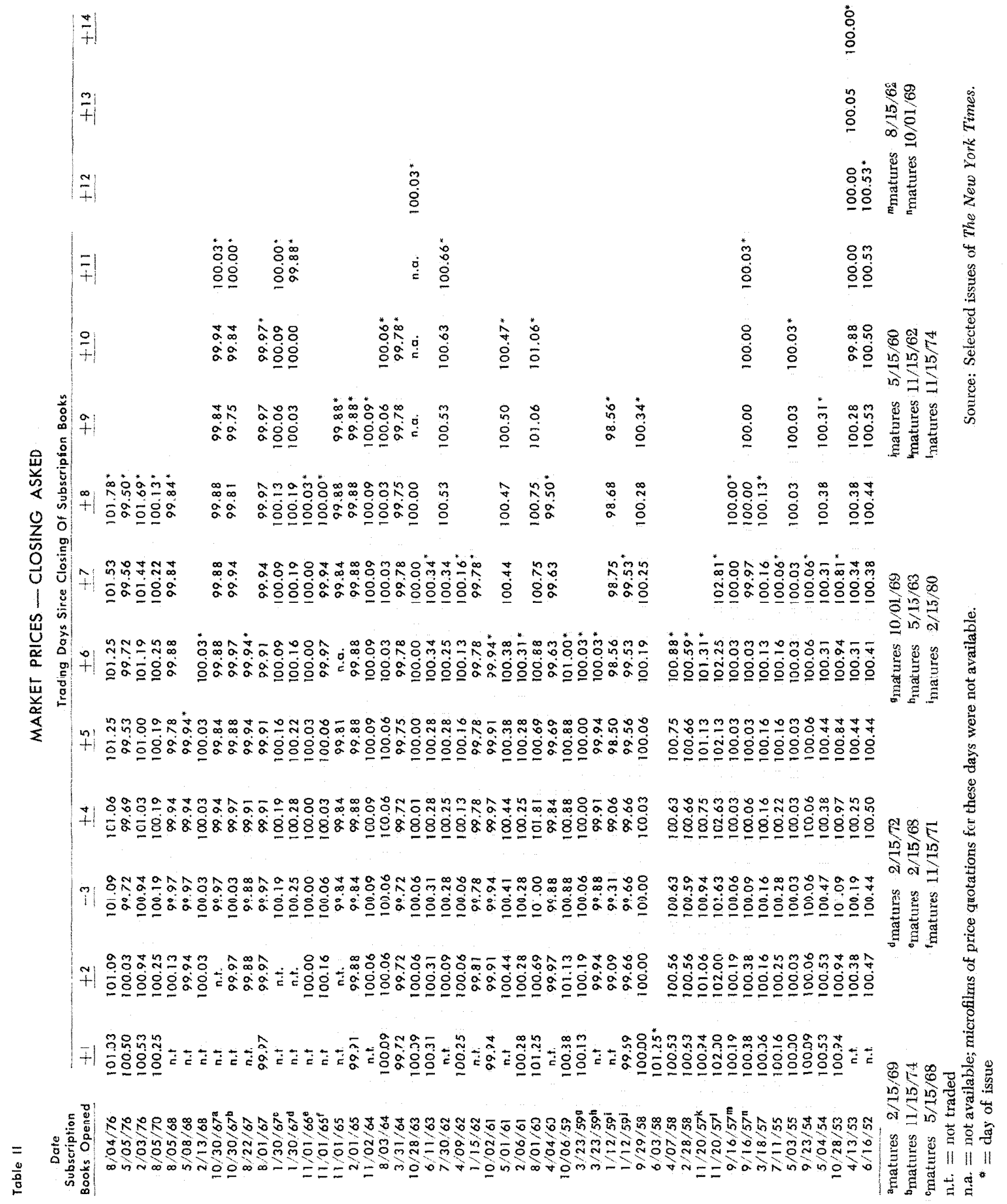


The choice of the measure of the market price does not seem to be a significant factor in affecting the major conclusions to be drawn from Table III. In all cases, the price and interest elasticities are large. ${ }^{15}$ The mean price and interest elasticities (shown at the bottom of Table III) using the price on the first trading day are not generally as large as the elasticities using other price measures, with one exception, but the larger elasticity values using the alternative price measures are also more variable across issues. The price elasticities for longer maturities (five years and over) seem to be considerably smaller on average than those for the shorter maturities (one to five years $)$. Since a given price elasticity, $\varepsilon(\mathbf{Q}, \mathbf{P})$, produces a larger yield elasticity, $\varepsilon(Q, R)$, the longer the termto-maturity, this difference between the average price elasticities of the different maturities is offset, with the result that the average yield elasticities for the two maturity groupings are not significantly different from each other. ${ }^{16}$

For all of the measured series, whether price elasticities or yield elasticities, the values computed for

15. We have adjusted several of the elasticity computations under the assumption that the total bid, $Q_{s}$, is inflated (see footnote 7). In one case, it is assumed that the true value of $Q_{\text {s }}$ called $Q_{s}^{*}$, exceeds $Q_{i}$ by half of the amount by which $Q_{s}$ exceeds $Q_{i}$; that is, $Q_{s}^{3}=Q_{i}+0.5\left(Q_{s}-Q_{1}\right)$. In the second case, $Q^{*}$ is assumed to exceed $Q_{i}$ by only onefourth of the amount by which $Q_{s}$ exceeds $Q_{i}$; that is, $Q_{s}{ }^{*}$ $=Q_{1}+0.25\left(Q_{s}-Q_{i}\right)$. Under the former assumption, the elasticities reported in Table III would be multiplied by a correction factor averaging 0.65 , while under the latter assumption the correction factor averages 0.4. Biases of this magnitude in ouf computations do not substantively alter our conclusions.

16To be precise, a given price elasticity produces a larger yield elasticity the longer the duration of the bonds. Duration and term-to-maturity are identical measures of the time structure of bonds for non-coupon bonds, such as Treasury bills. But for coupon bonds, such as the Treasury notes and bonds discussed in this paper, furation and term-to-maturity are not equivalent. Howeve, for coupon bonds selling at par or premiuns, ditration increases with term-to-maturity, so that the stated relationship holds for almost all the issues listed in Tables 1 and II. For conpon bonds selling at discounts, duration increases with term-tomaturity up to a maximum, and then decreases as tern-to-maturity increases. This case, although possible, does not appear. to be of significant inportance in the results reported here.

For a discussion of duration, see Michael H. Hopewell and George G. Kanfman, "Bond Price Volatility and Term to Maturity: A Generalized Respecification," The Amertican Economic Reviets (September 1973), pp. 749-53; and Roman L. Weil, "Macaulay's Duration: An Appreciation," The Journal of Business (October 1973), pp. $589-92$. form:

The fommla relating price and yield elasticities is of the

$$
\begin{aligned}
\varepsilon(\mathrm{Q}, \mathrm{P}) & =\frac{\mathrm{dQ}}{\mathrm{Q}} \frac{\mathrm{P}}{\mathrm{dP}}=-\frac{\mathrm{dQ}}{\mathrm{Q}}\left(-\frac{1}{\mathrm{D}} \frac{1+\mathrm{R}}{\mathrm{R}}\right) \frac{\mathrm{R}}{\mathrm{dR}} \\
& =-\frac{1}{\mathrm{D}} \frac{1+\mathbf{R}}{\mathbf{R}} \varepsilon(\mathrm{Q}, \mathrm{R})
\end{aligned}
$$

where $\mathrm{D}=$ duration the individual securities tend to exhibit considerable variance across issues, as indicated by the series' standard deviations (bottom of Table III). The large variance among issues produces a standard deviation which is large relative to the mean elasticity. However, the computed means on all elasticity measures, for both maturity groupings, are significantly different from zero at the $2 \frac{1 / 2}{2}$ percent level. In thirteen of the sixteen cases, the mean price and yield elasticities are significantly different from zero at the 0.5 percent level. ${ }^{17}$

Given the large elasticities in Table III, the question arises as to whether these results can be generalized to conclude that the price and interest elasticities of demand for other Treasury securities are also large. Treating the elasticities in Table III as sample observations drawn from a population of elasticities for all Treasury securities, the probability that the own price or interest elasticity is larger than a specified value for any security can be computed. ${ }^{18}$ If the probability is high that the elasticity of demand is large for any given security, then we have greater confidence that the large elasticities in Table III are representative of the elasticities of demand for other Treasury issues. Under the assumption that the individual elasticity estimates are drawn from a normal distribution, the probabilities that the elasticities are larger than 1, 5, 10, 25, and 50 are computed in Table IV. From these results it is seen that the probability is very high that the Government debt, both long- and short-term, is very elastic with respect to its own price or yield, all other factors held constant.

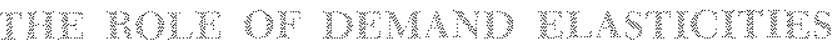 MN THE ASBSGMEN BH

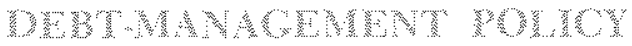

Discretionary debt-management policy, as usually defined, deals with the manipulation of the relative$$
=\frac{1+R}{\mathbf{R}}-\frac{F}{\mathrm{P}} \frac{[1+\mathbf{R}-\mathrm{n}(\mathrm{R}-\mathrm{c})]}{\mathrm{R}(1+\mathrm{R})^{\mathrm{n}}}
$$$$
\text { and } F=\text { face value of bonds }
$$$$
\mathrm{P}=\text { price of bonds }
$$$$
\mathbf{R}=\text { yield on bonds }
$$$$
\mathrm{c}=\text { coupon rate on bonds }
$$$$
Q=\text { quantity of bonds }
$$

Tests for the equality of the average yield elasticities for the two maturity groupings were performed using t-tests at the 5 percent level (two-tailed test).

$1 T$ A one-tailed test was applied in both cases.

${ }^{18}$ In this case, the "population of elasticities" is more specifically the elasticities of demand for Treasury securities over the range of the market demand curve in which the Treasury operates.
} 
Trbie ill

ESTIMATED PRICE AND INTEREST ELASTICITIES FOR VARIOUS SUBSCRIPTION ISSUES: $1952.1976 *$

\begin{tabular}{|c|c|c|c|c|c|c|c|c|c|c|}
\hline bols & Termor & $\begin{array}{l}\text { Moturity } \\
\text { Months }\end{array}$ & $8(0, P)$ & $\left(10, P_{2}\right)$ & $\varepsilon\left(\mathrm{O}_{\mathrm{B}}\right)$ & $\left(10, P_{4}\right)$ & $E\left(\mathrm{R}_{1}\right)$ & $8\left(0, R_{2}\right)$ & $e\left(0, \mathrm{R}_{3}\right)$ & $\varepsilon\left(a, R_{4}\right)$ \\
\hline $0 / 29,58$ & 1 & 1 & & 4361,15 & 67131 & 256,95 & - & 160.13 & 24,36 & 9.15 \\
\hline $5 / 08 / 60$ & 1 & 3 & 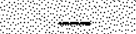 & 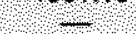 & 1 & 1 & ? & 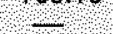 & 4 & \\
\hline $2 / 13 / 68$ & 1 & 3 & 2851.60 & 2851800 & 2851.80 & $2651 \% 60$ & 191.73 & 191,73 & 191.73 & 101.73 \\
\hline $10 / 30 / 67$ & 1 & 3 & 4 & 14 & 4 & 3067.66 & ?ै? & - & $2=$ & 206.24 \\
\hline $8 / 01 / 67$ & 1 & 3 & 304478 & 9133.42 & 9133.42 & 304478 & 19.02 & 58698 & 336.98 & 193.02 \\
\hline $1 / 30 / 67$ & 1 & 3 & 653,38 & 7776.46 & 875.45 & $164, \% 4$ & 3703 & 4410 & 4985 & 0.6 .67 \\
\hline $11,01 / 66$ & 1 & 3 & 4 & 10301,10 & $10301 / 10$ & 3434.04 & $\stackrel{2}{2}$ & 722.59 & 722.59 & 23088 \\
\hline $5 / 03 / 55$ & 1 & 3 & 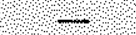 & 1546,53 & 103107 & 103107 & $=$ & 36.21 & 24.57 & 24.57 \\
\hline $1 / 11 / 39$ & 1 & 4 & 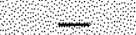 & 40 & 48 & 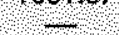 & 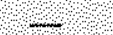 & 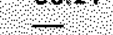 & 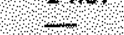 & $1 \%$ \\
\hline $3 / 31 / 04$ & 1 & 4 & 11272.80 & 751558 & 4500,80 & 201905 & 661,38 & 4120,46 & 242.05 & 15092 \\
\hline $8 / 05 / 70$ & 1 & 8 & 590.71 & 681,45 & 681.45 & 983.92 & 60.88 & 70.46 & 70.46 & 201,74 \\
\hline $11 / 01 / 63$ & 1 & 6 & 6416.39 & 6416.39 & 3208.36 & 1283.54 & 400.72 & 400,72 & 200.20 & 7989 \\
\hline $1 / / 02 / 64$ & 1 & 6 & 2691,09 & 2018.52 & 1794.33 & 179.33 & $1,52.92$ & 114,40 & 101.68 & 10168 \\
\hline $6 / 03 / 64$ & 4 & 6 & 19872 & 255473 & 3576.27 & 2960.37 & 110.03 & 140,48 & 197.03 & 164.04 \\
\hline $10.28 \% 63$ & 1 & 6 & 1553.27 & 3493.98 & 46.58 .60 & 4658.40 & 86.63 & 19268 & 25714 & 25714 \\
\hline 2,00601 & 1 & 6 & 50750 & 526.27 & 507.50 & 458.46 & 23.18 & 2408 & 23.18 & 20.93 \\
\hline $10 / 02 / 61$ & 1 & 7 & 143599 & 1581,28 & 1555.62 & 1435.90 & 71.68 & 85.95 & 7188 & 71.88 \\
\hline $2 / 01 / 65$ & 1 & 9 & 2010.93 & 6820.99 & $5870 \% 9$ & 582009 & 197.65 & 39617 & 396.17 & 39.6 .17 \\
\hline $3.01 / 61$ & 2 & 0 & 41996 & 450.63 & 419.96 & 3093.22 & 25.35 & $27 \% 20$ & 25.33 & 23.62 \\
\hline $4 \% 04,60$ & 2 & 1 & $(-$ & 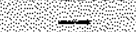 & 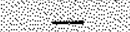 & 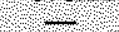 & 0 & 40 & ? & 4 \\
\hline $9 / 23 / 54$ & 2 & 7.5 & 755.93 & 971,81 & $1133 \% 2$ & 1733.72 & 31.23 & 40.58 & 45.60 & 4.7 .0 \\
\hline $3 / 18 / 57$ & 3 & 1,5 & 3208.13 & 1375.46 & 1375,46 & $1481 \times 1 \%$ & 336.60 & $4,2,0$ & 142.29 & 152.06 \\
\hline $8 / 22 / 67$ & 3 & $5 \longdiv { 5 }$ & ? & 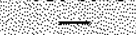 & ?. & 442083 & 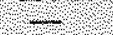 & 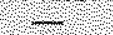 & 3 & 785.86 \\
\hline $3 / 23 / 59$ & 4 & 1,5 & 3 & ?-ב & 4 & 1953049 & -3 & 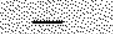 & 1.4 & 202.61 \\
\hline $5.04 \times 54$ & 4 & 9. & 172.31 & 104,25 & 228.16 & 294,27 & 14.14 & 15996 & 1895 & 24.66 \\
\hline $10 / 06 / 59$ & 4 & 10 & 78313 & 173.37 & 17140 & 161.25 & 38.13 & 35.98 & 35.65 & 33.7 \\
\hline $44 / 07 / 50$ & 4 & 10 & 264.24 & 225.98 & $2 / 2,13$ & 159.42 & 30.63 & 2606 & 24.41 & 18.19 \\
\hline $9 / 10767$ & 4 & 11 & 607.63 & 1153,08 & 1648,29 & 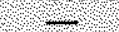 & 106.69 & 200.08 & 306.92 & 3 \\
\hline $1,1 / 20 / 57$ & 4 & 113 & 213.48 & 20905 & 196.81 & 153.46 & 35.00 & 34.16 & 32.13 & 24,82 \\
\hline $1 / 30,67$ & 5 & 0 & 394.48 & 414.31 & 487.93 & 965.08 & 82,70 & 86.49 & 102.51 & 204,4 \\
\hline $11,01 \times 66$ & 5 & 0 & 130773 & 3485,54 & 697003 & $=$ & 307.67 & 801,63 & 160431 & ?ב \\
\hline $6 / 16 / 52$ & 5 & 1115 & 210.34 & 220.07 & 219.34 & 19.457 & 28.22 & 29.64 & 28.22 & 25.19 \\
\hline $8 / 05 / 60$ & 6 & 0 & 285.64 & 455,12 & 502.13 & 66168 & 80.85 & 129.29 & 14274 & 168.39 \\
\hline $4 / 00 \%, 02$ & 6 & 4 & 704,65 & $1354,2 \%$ & 1257.62 & 1700.53 & $1,45.74$ & 27.03 & 26303 & 226.63 \\
\hline $7 / 30 / 62$ & 6 & 6 & 1486.65 & 58214 & 352.61 & 203.00 & 333.68 & 13307 & 80.38 & 45.44 \\
\hline $2,03 / 76$ & 3 & 0 & 298.03 & 178.27 & 144.39 & 94.26 & 1125.58 & 74,88 & 60.26 & 3907 \\
\hline $10 \% 30 / 67$ & 7 & 0 & 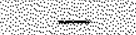 & - & 3 & ? & 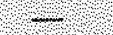 & - & 4 & $=$ \\
\hline $6 / 11163$ & 7 & 2 & 692.63 & 71568 & 692,65 & 631.61 & 1170,43 & 117003 & 170.43 & 154.84 \\
\hline $1,16,62$ & 7 & 8.5. & & 100805 & 100805 & 134 & 181 & 371,79 & 271.79 & 326.19 \\
\hline $8 \times 01 / 60$ & 7 & 9 & 128.52 & 14727 & 162.06 & 151,41 & 32.28 & 17715 & 40,12 & 38.11 \\
\hline $10 / 28 / 53$ & 2 & 10 & & 182,30 & 15 & 21500 & 35.14 & 34 & 35.41 & 4077 \\
\hline $2 / 28 / 58$ & 8 & 5.5 & 24.909 & 253.10 & 253.10 & 265.93 & 5.43 & 5876 & 5376 & 58.62 \\
\hline $5 / 05 / 76$ & 10 & 0 & & 10 & $\longrightarrow$ & 3 & 68.69 & 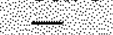 & $\longrightarrow$ & 3 \\
\hline $8,04 / 70$ & 10 & 0 & 108 & 101.58 & 68.75 & 82.99 & 58.71 & 54.66 & 4776 & 3377 \\
\hline $3 / 23,59$ & 10 & 6 & 72110 & 117149 & 1038.78 & 312319 & 249.35 & 415,89 & 46794 & 1248.62 \\
\hline $90 / 16 / 57$ & 12 & 0 & 553.65 & 1106.5 & 2334.25 & 7000.64 & 208.94 & 418.92 & 932.23 & 279679 \\
\hline $11 / 20 / 57$ & 16 & 115 & 96. & 84.44 & 8199 & 68.69 & 46.14 & 39.57 & 38.48 & 32.12 \\
\hline $1 / 12 \% 59$ & 21 & 1 & 815.62 & 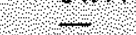 & 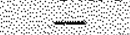 & $=$ & 502,49 & 4 & 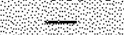 & 4 \\
\hline $6 / 03 / 58$ & 26 & 11 & 116.90 & 116.9 & 116.99 & 110.99 & 67.92 & 6792 & 6792 & 67.9 \\
\hline $4 / 7353$ & 30 & 1,5 & 34720 & 425.45 & $693 \%$ & 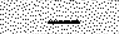 & 193,86 & 237,1 & 388041 & \\
\hline $7 / 1,65$ & 89 & 7 & 472,78 & 360.30 & 420.29 & 126011 & $3,3,55$ & 251,57 & 323.55 & 1133.38 \\
\hline Meturities & & x & 208703 & 270717 & 2459,26 & 1908.69 & 140.24 & 176.89 & 162.70 & 148.23 \\
\hline 110,5 & & 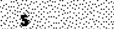 & 2068,49 & 307901 & 279971 & $1568 \times 6$ & 16.41 & 19116 & 183.96 & 168.71 \\
\hline reors & & & 20 & 23 & 23 & 25 & 20 & 23 & 13 & 25 \\
\hline & & $H_{1} \|_{1}=0$ & 3.50 & 4.43 & 1,21 & 608 & 3.86 & 9.4 .4 & 4,24 & 4.39 \\
\hline Moturifes & & x: & 475.63 & $651 / 14$ & 911,20 & 102711 & 156.74 & 188.82 & $269 \cdot 57$ & 391.90 \\
\hline Over 5 & & 7). & 385.55 & 79284 & 1574.45 & 1722.16 & 126.68 & 19373 & 391.93 & 722.08 \\
\hline yeors & & N & 21 & 19 & 19 & 17 & 21.5 & 19 & 99 & 17 \\
\hline & & & 5.65 & 3,56 & 2,52 & 2,46 & 5.67 & 4.25 & 300 & \\
\hline
\end{tabular}

OElasticities in absolite talue

$\bar{x}=$ sample near.

$s=$ sample stanctard deviation

$\mathrm{N}-\mathrm{C}$ number of obsetvations in sample

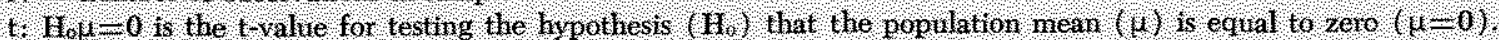

$\varepsilon(0, p)=$ the estimated price elasticity of demand for a secinty, asing pitee 1 t as the neasere of the narket price.

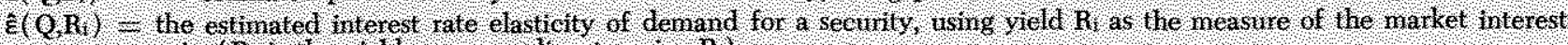
rate ( $\mathrm{R}$, is the yeld correspenting 10 price $\mathrm{P}$ )

$\mathrm{P}_{1}, \mathrm{P}_{2}, \mathrm{P}_{3}, \mathrm{P}$. Measures of market jrices as defined in the text.

$\mathrm{n}, \mathrm{n}, \mathrm{n}, \mathrm{n}$, Measures of market yelds corresponding 10 he briee neasures. 
Table Iy

PROBABILTIES THAT OWN PRICE AND INTEREST ELASTICITIES ARE GREATER IHAN SPECIFIED YALUES

\begin{tabular}{|c|c|c|c|c|c|c|c|c|}
\hline \multirow[b]{2}{*}{ Volve $(x)$} & \multicolumn{4}{|c|}{$p r[\varepsilon(\propto, P])>\times]$} & \multicolumn{4}{|c|}{$\operatorname{Pr}[\in(\mathrm{O}, \mathrm{R})>\mathrm{x}]$} \\
\hline & $\varepsilon\left(0, p_{1}\right)$ & $E\left(Q_{1} \varepsilon_{2}\right)$ & $\varepsilon\left(0, P_{3}\right)$ & $E\left(0, P_{4}\right)$ & $\varepsilon\left(\mathrm{Q}, \mathrm{R}_{1}\right)$ & $\mathbb{E}\left(Q_{2} \mathbb{R}_{2}\right)$ & $\varepsilon\left(Q_{2} R_{3}\right)$ & $\varepsilon\left(Q, R_{0}\right)$ \\
\hline \multicolumn{9}{|c|}{ Matrity $1-5$ Years } \\
\hline 10 & 78 & 82 & 81 & 89 & 80 & 82 & 81 & 8 \\
\hline 30 & 78 & 82 & 81 & 89 & 80 & 82 & 80 & 80 \\
\hline 100 & 78 & 82 & 81 & 89 & 78 & 81 & 80 & 79 \\
\hline 250 & 78 & 82 & 81 & 89 & 76 & 79 & 77 & 77 \\
\hline 500 & 7 & 82 & 81 & 88 & 71 & 75 & 73 & 72 \\
\hline \multicolumn{9}{|c|}{ Haturity Over 5 Years } \\
\hline 10 & 89 & 79 & 72 & 72 & 89 & 83 & 75 & 71 \\
\hline 50 & 89 & 79 & 72 & 72 & 88 & 83 & 75 & 70 \\
\hline 100 & 89 & 79 & 72 & 72 & 88 & 82 & 75 & 70 \\
\hline 250 & 80 & 79 & $n$ & 72 & 85 & 80 & 73 & 69 \\
\hline 500 & 87 & 78 & 71 & 71 & 80 & 76 & 71 & 68 \\
\hline
\end{tabular}

maturity composition of a given stock of interestbearing Government debt to accomplish a desired change in the term structure of interest rates. Two major hypotheses exist in the term-structure literature which have conflicting implications for the effectiveness of such debt-management policies. The first hypothesis in its purest form is known as the "expectations hypothesis" of the term structure. This hypothesis maintains that interest rates on long-term securities are determined as a geometric average of current short-term interest rates, and the expectations of future short-term interest rates that will prevail over the life of the long-term security. ${ }^{19}$ Given short-term rates and expectations regarding future short-term rates, the long-term rate is determined independently of the maturity structure of the outstanding debt.

The second hypothesis was originally formulated as a "segmented markets" theory, but in recent years has been revised and has come to be known as a "preferred habitat" theory. ${ }^{20}$ In this latter form, the theory holds that different classes of lenders (and in the case of private debt, borrowers) have a preference for different maturity segments of the debt market. These preferred maturities, or preferred habitats, are assumed to be well-defined for different groups of market participants, but they are not mu-

\footnotetext{
19 Meiselnan, The Term Structure of Interest Rates; Malkiel, The Term Structure of Interest Rates.

"Oohn M. Culbertson, "The Term Structure of Interest Rates," The Quarterly Journal of Economics (November 1957), pp. 485-517; Modigliani and Sutch, "Innovations in Interest Rate Policy," and "Debt Management and the Tern Structure of Interest Rates;" and Nelson, The Term Structure of Interest Rates.
}

tually exclusive across groups as the proponents of the "segmented markets" hypothesis maintained. ${ }^{21}$ Thus, for the market as a whole, arbitrage will occur across the maturity spectrum, and the short-term rate and expectations of future short-term rates should be relevant in determining the long-term rate. However, since individual groups of market participants are hypothesized to have well-defined maturity preferences, demand and supply imbalances in a particular maturity segment cannot be completely arbitraged away. Consequently, the theory maintains that substantial changes in the maturity composition of the outstanding debt should also have an influence on the long-term rate, given the short-term rate and expectations of future short-term rates.

In two articles published in 1966 and 1967 , Modigliani and Sutch investigated the effects of various measures of the maturity composition of the Federal debt on the average yields on long-term Treasury securities. ${ }^{22}$ They found very little empirical evidence that debt variables significantly affect the long-term rate. Current and lagged values of the short-term rate, which can be considered as proxy measures for expected future short-term rates, accounted for almost all the variation in long-term rates. Modigliani and Sutch concluded that debtmanagement effects, if they exist, have only a small impact on the long-term rate.

\footnotetext{
\$1Mdigliani and Sutch, "Innovations in Interest Rate Policy;" Nelson, The Term Structure of Interest Rates.

¿2Modigliani and Sutch, "Innovations in Interest Rate Policy" and Debt Managenenen and the Term Structure of Interest Rates."
} 
Other researchers who have done similar empirical work have also found that such debt-management effects are small. ${ }^{23}$ Some have maintained that problems of measuring the various debt variables, and especially the inability to accurately measure a debt variable which includes all debt and not only Treasury debt, may bias these empirical tests. ${ }^{24}$ Thus, it is argued that debt-management policies may have a significantly larger effect on long-term rates than has been reported, but that measurement problems prevent its empirical identification. Discretionary debtmanagement policies, according to this line of argument, may yet be found to be very effective in changing the structure of interest rates.

Utilizing the information reported in the first section of this paper on the elasticities of demand for Treasury securities, it can be shown that there are other reasons to conclude that even if debt-management variables affect long-term rates, the effect is small. This can be demonstrated by deriving an equation similar to that investigated by Modigliani and Sutch, but starting from demand functions for Government securities rather than the preferred-habitat theory.

Consider the following market demand functions for long- and short-term Government debt:

$$
\begin{aligned}
& \ln \left(Q_{s}^{d} / W\right)=\alpha_{\theta}+\alpha_{1} R_{s}+\alpha_{2} R^{\mathrm{e}}-\alpha_{3} R_{l}+Z_{s} \lambda_{s} \\
& \ln \left(Q_{1}^{d} / W\right)=\beta_{0}-\beta_{1} R_{s}-\beta_{2} R_{s}^{\mathrm{e}}+\beta_{3} R_{1}+Z_{3} \lambda_{1}
\end{aligned}
$$

where:

$$
\begin{aligned}
& Q_{s}^{d} \text { is the quantity demanded of short-term debt } \\
& Q_{1}^{A} \text { is the quantity demanded of long-tem debt } \\
& \mathbf{R}_{\mathrm{s}} \text { is the current interest rate on short-term debt } \\
& R_{i} \quad \text { is the current interest rate on long-term debt } \\
& R_{5} \text { is the expected future interest rate on short* } \\
& \text { terma debt } \\
& W \text { is total wealth } \\
& Z_{s}, Z_{3} \text { are vectors of other variables affecting } Q_{s} \text { and } \\
& Q_{i} \text {, respectively, including rates of return on }
\end{aligned}
$$

and $\alpha_{1}>0, \beta_{i}>0, \lambda_{5}$ and $\lambda_{1}$ are coefficients. Since the demand functions are expressed in terms of interest rates rather than prices, the own elasticities of demand are positive and the cross elasticities are negative. The functional form indicated in equations

\footnotetext{
23 For example, Frank de Leeuw, "A Model of Financial Belavior" in The Brookings Quarterly Econometric Modet of the United States, ed. James $S$. Duesenberry et al. (Chicago: Rand McNaly \& Company, 1965); Neil Wallace, "The Term Structure of Interest Rates and The Maturity Composition of the Federal Debt" (Ph.D. dissertation, University of Chicago, December 1964).

24See the "Discussions" and "Comments" to Modigliani and Sutch, "Innovations in Interest Rate Policy," and "Debt Management and the "erm Structure of Interest Rates."
}

(1) and (2) has been chosen primarily for expositional convenience. However, this form has been used in recent studies of asset demand functions, and recent theoretical work suggests that it is preferred to the more traditional linear and $\log$-linear specifications. ${ }^{25}$ The restriction of wealth elasticities to unity is maintained to eliminate detail which is not relevant to this discussion. None of the conclusions of the subsequent analysis is affected by this constraint. ${ }^{26}$ By subtracting equation (2) from equation (1) the following expression can be obtained: $:^{2 \tau}$

$$
\begin{gathered}
\ln \left(Q_{s} / W\right)-\ln \left(Q_{1} / W\right)=\ln \left(Q_{s} / Q_{1}\right)=\left(\alpha_{0}-\beta_{0}\right)+ \\
\left(\alpha_{1}+\beta_{1}\right) R_{s}+ \\
\left(\alpha_{2}+\beta_{2}\right) R_{s}^{e}-\left(\alpha_{3}+\beta_{3}\right) R_{1}+Z_{s} \lambda_{s}-Z_{1} \lambda_{1}
\end{gathered}
$$

This equation, in turn, can be solved for the long-term rate to obtain:

$$
\begin{gathered}
\mathrm{R}_{1}=\left(\frac{\alpha_{0}-\beta_{0}}{\alpha_{3}+\beta_{3}}\right)+\left(\frac{\alpha_{1}+\beta_{1}}{\alpha_{3}+\beta_{3}}\right) \mathrm{R}_{5}+\left(\frac{\alpha_{2}+\beta_{2}}{\alpha_{3}+\beta_{3}}\right) \mathrm{R}_{5}^{\mathrm{e}} \\
-\left(\frac{1}{\alpha_{3}+\beta_{3}}\right) \operatorname{lin}\left(\mathrm{Q}_{\mathrm{s}} / \mathrm{Q}_{1}\right)+\frac{\mathrm{Z}_{\mathrm{s}} \lambda_{5}}{\alpha_{3}+\beta_{3}}-\frac{\mathrm{Z}_{1} \lambda_{1}}{\alpha_{3}+\beta_{3}}
\end{gathered}
$$

By appropriate manipulation, this equation can be rewritten as:

$$
\begin{aligned}
R_{1} & =\left(\frac{\alpha_{0}-\beta_{0}}{\alpha_{3}+\beta_{3}}\right)+\left(\frac{\alpha_{1}+\beta_{1}}{\alpha_{3}+\beta_{3}}\right) R_{3}+\left(\frac{\alpha_{2}+\beta_{2}}{\alpha_{3}+\beta_{3}}\right) R_{3}^{e} \\
& +\left(\frac{1}{\alpha_{3}+\beta_{3}}\right)\left(\frac{Q_{1}}{D E B T}\right)-\left(\frac{1}{\alpha_{3}+\beta_{3}}\right)\left(\frac{Q_{\mathrm{g}}}{\mathrm{DEBT}}\right)+\varepsilon
\end{aligned}
$$

where DEBT is the quantity of debt outstanding at all maturities, say short $\left(Q_{s}\right)$, intermediate $\left(Q_{n}\right)$ and long $\left(Q_{1}\right)$, and where the influence of the (unspecified) variables in the vectors $Z_{s}$ and $Z_{1}$ have been impounded in the error term $\varepsilon^{28}$

"wphillip Cagan and Ama I. Schwartz, "Has the Growth of Money Substitutes Hindered Monetary Policy?" Joutnal of Money, Credit and Banking (May 1975), pp. 137-59; J. B. Ramsey and $R$. H. Rasche, "The Velocity of $M 2$ and of Its Components," Workshop Paper No. 7504 (Michigan State University, Jume 1976); Ramsey, "Limiting Functional Forms for Market Demand Curves," Econometrica (March 1972), pp. $327-41$.

26 Equations (1) and (2), with the constrained wealth elasticities, are consistent with the general asset demand specifcations suggested by james Tobin, "An Essay on Principles of Debt Management, in Fiscal and Debt Management Policies, by William Fellner et al. (Englewood Cliffs, N.J.: Prentice-Hall, Inc., 1963), p, 216, and "A Ceneral Equilibrium Approach to Monetary Theory," Joumal of Money, Credit and Banking (Febraary 1969), p. 24.

27It is implicitly assumed here that the supplies of $\mathrm{Q}_{\mathrm{s}}$ and $\mathrm{Q}$ are exogenously determined by the Treasury, so that the superscripts on these two variables are dropped.

$28 \ln \left(Q_{s} / Q_{1}\right)=\ln \left[\left(Q_{s} / D E B T\right)\left(\frac{D_{E B T}}{Q_{1}}\right)\right]=\ln \left(Q_{s} / D E B T\right)$

- $\ln \left(Q_{1} / \mathrm{DEBT}\right)$ where DEBT is the quantity of debt outstanding at all maturities, say short $\left(Q_{3}\right)$, intemediate $\left(Q_{n}\right)$ 
Equation (5) is one form of the equation which Modigliani and Sutch (1966) proposed and tested as the "preferred habitat" model. ${ }^{29}$ It can be seen from equation (5) that the magnitude of the parameters $\alpha_{3}$ and $\beta_{3}$ will be crucial in determining whether one can find sizable impacts of the maturity composition of the debt on the long-term rate. If either of these parameters is very large, then the true coefficients of the maturity-composition variables are very small. In addition, since the variation of the maturity structure of the debt is quite limited in any sample period, the precision of the estimates of these coefficients will not be very high. Consequently, it is quite likely that if either $\alpha_{3}$ or $\beta_{3}$ is large, it will be possible to reject the hypothesis that changes in the maturity structure of the debt have a significant impact on the long-term rate, for a given short-term rate.

The parameters in equation (5), such as $\beta_{3}$ and $\alpha_{3}$, are associated with the elasticities and crosselasticities of demand for short and long-term Government securities, which can be derived from equations (1) and (2). The interest rate elasticity of demand for long-term debt $\left(Q_{1}\right)$ is equal to $\beta_{3} R_{1}$, while the interest elasticity of demand for short-term debt $\left(Q_{s}\right)$ is equal to $\alpha_{1} R_{s}$. 30 The cross-elasticity of demand for short-term debt with respect to the longterm interest rate is given by $-\alpha_{3} R_{1}{ }^{31}$ Although there is insufficient information to estimate $\alpha_{3}$, estimates of $\beta_{3}$ and $\alpha_{1}$ for individual Treasury securities

$$
\begin{aligned}
& \text { and long }\left(Q_{1}\right) \text {. Then } \ln \left(Q_{s} / D E B T\right)=\ln \left(1-\frac{Q_{1}+Q_{n}}{D E B T}\right) \text {. } \\
& \text { But } \ln \left(1-\frac{Q_{1}+Q_{n}}{D E B T}\right)=-\left(\frac{Q_{n}+Q_{1}}{D E B T}\right) \text {. Similarly } \\
& \ln \left(\frac{Q_{1}}{D E B T}\right)=-\frac{Q_{s}+Q_{n}}{D E B T} \text {. Therefore, } \ln \left(Q_{s} / Q_{1}\right) \approx \\
& -\frac{\left(Q_{n}+Q_{1}\right)}{D E B T}+\frac{\left(Q_{s}+Q_{n}\right)}{D E B T}=\frac{Q_{s}}{D E B T}-\frac{Q_{1}}{D E B T} .
\end{aligned}
$$

This approximation $[\ln (1-\mathrm{X}) \simeq-\mathrm{X}]$ is accurate only for values of $X$ between -0.3 and +0.3 ; shat is, when the ratio of the type of debt to total debt is less than $1 / 3$. How ever, its use here does not alter the conclusions drawn below, as will be shown later using the original tem: in $\left(Q_{2} / Q_{1}\right)$ The approximation is employed here in order to compare equation (5) with the work of Modigliani and Sutch.

29 Modigliani and Sutch assumed three maturity classes of debt - short, intermediate and long maturities - and approximated the expected future short-term rate by a distributed lag on past short-ferm rates. See Modigliani and Sutch, "Innovations in Interest Rate Policy."

$$
\begin{aligned}
& \theta_{\varepsilon}\left(Q_{1} R_{l}\right)=\frac{d \ln Q_{1}}{d R_{1}} R_{1}=\beta_{3} R_{1} \text { from equation }(2) ; \\
& \text { and } \varepsilon\left(Q_{s_{s}} R_{s}\right)=\frac{d \ln Q_{s}}{d R_{s}} R_{s}=\alpha_{1} R_{s} \text { from equation (1) } \\
& { }^{3} \varepsilon\left(Q_{5}, R_{1}\right)=\frac{d I_{1} Q_{3}}{d R_{l}} R_{1}=-\alpha_{3} F_{1} \text { from equation }(1)
\end{aligned}
$$

can be obtained from the elasticities of demand in Table III and measures of the interest rates which correspond to the prices in Table II. Estimates of $\alpha_{1}$ and $\beta_{3}$ are given in Table $V$ using the four measures of the market yields corresponding to the price measures discussed earlier. Very few of the values of $\alpha_{1}$ and $\beta_{3}$ in Table $V$ are below ten, and many are larger than twenty-five. The probability that $\beta_{3}$ is larger than a specified value can be computed in the same manner as the computations for the elasticities presented in Table IV. The probabilities that $\beta_{3}$ is greater than 10 and 25 are presented in Table VI. These probabilities are based on the data in Table $\mathrm{V}$ with maturities greater than 5 years.

From Table VI it can be seen that the data from the subscription sales suggest that it is highly probable that $\beta_{3}$ is larger than 10 . If this is the case for longterm debt as a whole, then the coefficients of the debt-composition variables in the "term structure" equation (5) are even more likely to be less than 0.1 , since the denominator of this coefficient is the sum of $\alpha_{3}$ and $\beta_{3}$ (and both are positive).

To illustrate the implication of such a parameter value, assume that 10 percent of the outstanding Government debt is switched from long-term to shortterm debt by an advance refunding operation. This would be a very large debt-management operation relative to the advance refunding operations which were attempted in the early 1960 s as part of "Operation Twist." With $\frac{1}{\alpha_{3}+\beta_{3}}=0.1$, an operation of such a magnitude would imply a change in the long-term rate of two basis points, according to equation (5)..$^{32}$ With this information, it is not surprising that attempts to estimate maturity-structure effects in specifications such as equation (5) have been notably unsuccessful. The evidence presented here suggests that even large changes in the maturity composition of the Government debt will have very minor impacts on the long-term rates on Government securities, and supports the position that debt management can be dismissed as a useful tool of stabilization policy.

The effects discussed above are not merely a function of the linear approximation of the debt vari-

$$
\begin{aligned}
& \frac{1}{\alpha_{3}+\beta_{3}} \frac{Q_{1}-0.1 \text { DEBT }}{\mathrm{DEBT}}-\frac{1}{\alpha_{3}+\beta_{3}} \frac{Q_{\mathrm{s}}+0.1 \mathrm{DEBT}}{\mathrm{DEBT}} \\
& =(0.1)\left[\frac{Q_{1}}{\mathrm{DEBT}}-0.1\right]-(0.1)\left[\frac{Q_{5}}{\mathrm{DEBT}}+0.1\right] \\
& =(0.1) \frac{Q_{1}}{\mathrm{DEBT}}-(0.1) \frac{Q_{5}}{\mathrm{DEBT}}-0.02
\end{aligned}
$$


Table $\mathrm{Y}$ ESTIMATES OF $\alpha_{1}$ AND $\beta_{3}$ USING VARIOUS MEASURES OF THE MARKET YIELD*

Dale
$9 / 29 / 58$
$5 / 09 / 68$
$2 / 13 / 68$
$10 / 30 / 67$
$8 / 01 / 67$
$1 / 30 / 67$
$11 / 01 / 66$
$5 / 03 / 55$
$1 / 12 / 59$
$3 / 31 / 64$
$8 / 05 / 70$
$11 / 01 / 65$
$11 / 02 / 64$
$8 / 03 / 64$
$10 / 28 / 63$
$2 / 06 / 61$
$10 / 02 / 61$
$2 / 01 / 65$
$5 / 01 / 61$
$4 / 04 / 60$
$0 / 23 / 54$
$3 / 18 / 57$
$8 / 22 / 67$
$3 / 23 / 59$
$5 / 04 / 54$
$10 / 06 / 59$
$4 / 07 / 58$
$9 / 16 / 57$
$11 / 20 / 57$

$\begin{array}{cc}\begin{array}{c}\text { Term-to Maturity } \\ \text { Years }\end{array} & 1 \\ & \text { Months } \\ 1 & 3 \\ 1 & 3 \\ 1 & 3 \\ 1 & 3 \\ 1 & 3 \\ 1 & 3 \\ 1 & 3 \\ 1 & 4 \\ 1 & 4 \\ 1 & 6 \\ 1 & 6 \\ 1 & 6 \\ 1 & 6 \\ 1 & 6 \\ 1 & 6 \\ 1 & 7 \\ 1 & 9 \\ 2 & 0 \\ 2 & 1 \\ 3 & 7.5 \\ 3 & 1.5 \\ 3 & 5.5 \\ 4 & 1.5 \\ 4 & 9 \\ 4 & 10 \\ 4 & 10 \\ 4 & 11 \\ 4 & 11.5\end{array}$

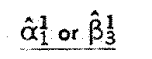

$1 / 30 / 67$

$11 / 01 / 66$

$6 / 16 / 5 ?$

$B / 05 / 68$

$4 / 09 / 62$

$7 / 30 / 62$

$2 / 03 / 76$

$10,20,167$

$6 / 11 / 63$

$8 / 01 / 60$

$10 / 28 / 53$

$2 / 28 / 58$

$5 / 05 / 76$

$8 / 04 / 76$

$3 / 23 / 59$

$9 / 16 / 57$

$11 / 20 / 57$

$1 / 12 / 59$

$6 / 03 / 58$

$4 / 13 / 53$

$7 / 11 / 55$

Maturities

1 to 5

Maturities

Over 5

years

$\beta_{a}=\frac{\varepsilon\left(Q_{\mathrm{L}}, R_{\mathrm{L}}\right)}{\mathbf{R}_{\mathrm{L}}}$ and $\alpha_{1}=\frac{\varepsilon\left(Q_{\mathrm{s}}, \mathbf{R}_{\mathrm{s}}\right)}{\mathrm{R}_{\mathrm{s}}}$.

$\hat{\beta}_{3}^{1}=\beta_{3}$ using $R_{1}$ as the market yield, as defined in Table III.

$x, s, N$, and $t: H, \mu=U$ are defined at the bottom of lable 11.

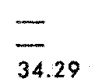

$+34.29$

36.64

8.08

=

$\overline{161.78}$

161.78
8.32

91.89

38.64

29.07

22.72

7.58
21.87

48.79

8.39

19.64

19.64
96.49

=

8.04

7.95
12.21

26.97

9.88

$\hat{\hat{\beta}_{3}^{\frac{1}{3}}}$

$\hat{\alpha}_{1}^{2}$ or $\hat{\beta}_{3}^{2}$

46.03

34.29

101:62

9.53

128.85

18.27

103.05

9.59

91.89

29.03

36.72

50.09

7.86
26.09

97.36

8.96

25.40

41.22

$\overline{9.01}$

9.01
7.53

10.47

52.57

9.66

$\underline{\hat{\beta}}_{3}^{2}$

17.64

56.70

12.32
14.44

39.34

83.75

.15 .90

43.15

44.96

8.75

13.43

18.67
8.80

7.48
62.57

62.57

52.76
12.15

12.15
123.61

21.35

60.06

108.10

34.96

39.38

20

39.33

33.70

5.35
18.40

149.53

12.92

22.94

73.55
33.60

9.56

44.02

67.41

10.01

13.14

19.11

0.97

104.21

105.26

10.71

21.35

73.36

84.11

41.53

37.29

23

5.34

46.32

41.76

19
4.83 $\hat{\alpha}_{1}^{3}$ or $\hat{\beta}_{3}^{3}$

7.22

$\overline{34.29}$

101.62

10.72
128.85

128.85

12.45

59.78

59.78
9.59

9.59
45.98

25.83

51.31

66.72

7.58
21.87

21.87
97.36

8.39

28.55

28.55
41.22

$-$

$\overline{10.60}$

7.46
9.85

9.85
77.04

9.12

$\underline{\hat{\beta}_{3}^{3}}$

21.71

12.32

12.32
25.29

25.29
70.61

20.43

7.73

43.15

67.41

10.93

13.52

19.11

6.11

117.22

233.58

10.44

21.35

119.92

108.10

37.97

35.47

23

5.13

64.62

81.22

19
3.47 $\hat{\alpha}_{1}^{4}$ or $\hat{\beta}_{3}^{4}$

2.88

34.29

36.89

36.64

19.99

41.29
12.45

37.

37.35
13.74

18.44

25.83

42.80

66.72

6.89
21.87

97.36

7.86

28.55

44.01

147.55

73.32

13.65

7.02
7.48

7.17

$\hat{\mathrm{B}}_{3}^{4}$

42.79

11.05

33.30

60.91

11.70

5.09

39.25

80.88

10.25

15.47

20.07

4.36

312.39

700.22

8.79

21.35

378.05

34.08

33.10

25

5.15

103.29

188.04

17

2.26 


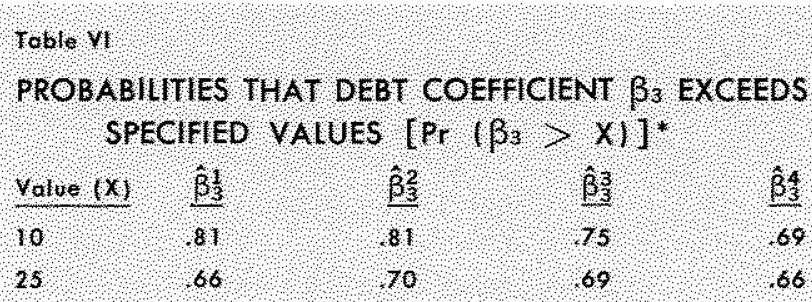

4 Based on data in TaWle $\checkmark$ with mannities greater than 5 years.

ables. ${ }^{33}$ To show this, the original term for the debt variables in equation $(4), \ln \left(Q_{s} / Q_{1}\right)$, has been calculated for the fiscal years 1967-1976 (Table VII). In Table VII, short- and long-term debt are defined in the conventional manner: short-term debt includes securities with one year or less to maturity; long-term debt includes securities with 10 or more years to maturity. If the coefficient on $\ln \left(Q_{s} / Q_{1}\right)$ in equation (4) is 0.1 (that is, if $1 /\left(\alpha_{3}+\beta_{3}\right)=0.1$, as given in the example above), then the impact of the debt variable on the long-term interest rate, given the short-term rate, has been less than 25 basis points over the period 1967.1976. ${ }^{34}$ Furthermore, debt-man-

3 See footnote 28 and equations (4) ard (5).

${ }^{34}$ Note that the assumption that the coefficient is 0,1 is a liberal one for assessing the effect of the debt variables. As noted earlier, it is very likely that the coefficient is smaller than 0.1 , which implies even snaller debt-management effects. agement operations can again be shown to have relatively small effects on the long-term rate for given short-term rates.

Table VIII presents the effects of two debt-management operations based on the data in Table VII: switching 10 percent of the outstanding Govemment debt from short-term to long-term debt, and switching 5 percent of the outstanding debt from long-term to short-term debt. ${ }^{35}$ In the former case, the longterm rate is raised by less than 15 basis points $(0.15$ percent) in each of the years. Thus, a shifting of 10 percent of the debt from the short- to long-term end of the maturity spectrum, which again is a large debt-management operation, results in a relatively small change in the longuterm rate, given the shortterm rate.

In the latter case, the shifting of 5 percent of the debt from the long- to short-term end of the maturity spectrum results in the long-term rate declining by less than 17 basis points ( 0.17 percent) in all but one

35 The debt variable, $1_{1}\left(Q_{\mathbb{s}} / Q_{1}\right)$, would now be:

$\ln \left[\left(Q_{\mathrm{s}}-0.1 \mathrm{DEBT}\right) /\left(\mathrm{Q}_{\mathrm{F}}+0.1 \mathrm{DEBT}\right)\right]$

or $\ln \left[\left(\mathrm{Q}_{s}+0.05 \mathrm{DEBT}\right) /\left(\mathrm{Q}_{1}-0.05 \mathrm{DEBT}\right)\right]$.

Note that if 10 percent of the debt were switched from long-to short-term, the longuterm debt would be wiped out in most years. Since such an operation is not very likely, a switch of 5 percent of the debt was used in Table VIII instead.

\footnotetext{
rable $\mathrm{nt}$

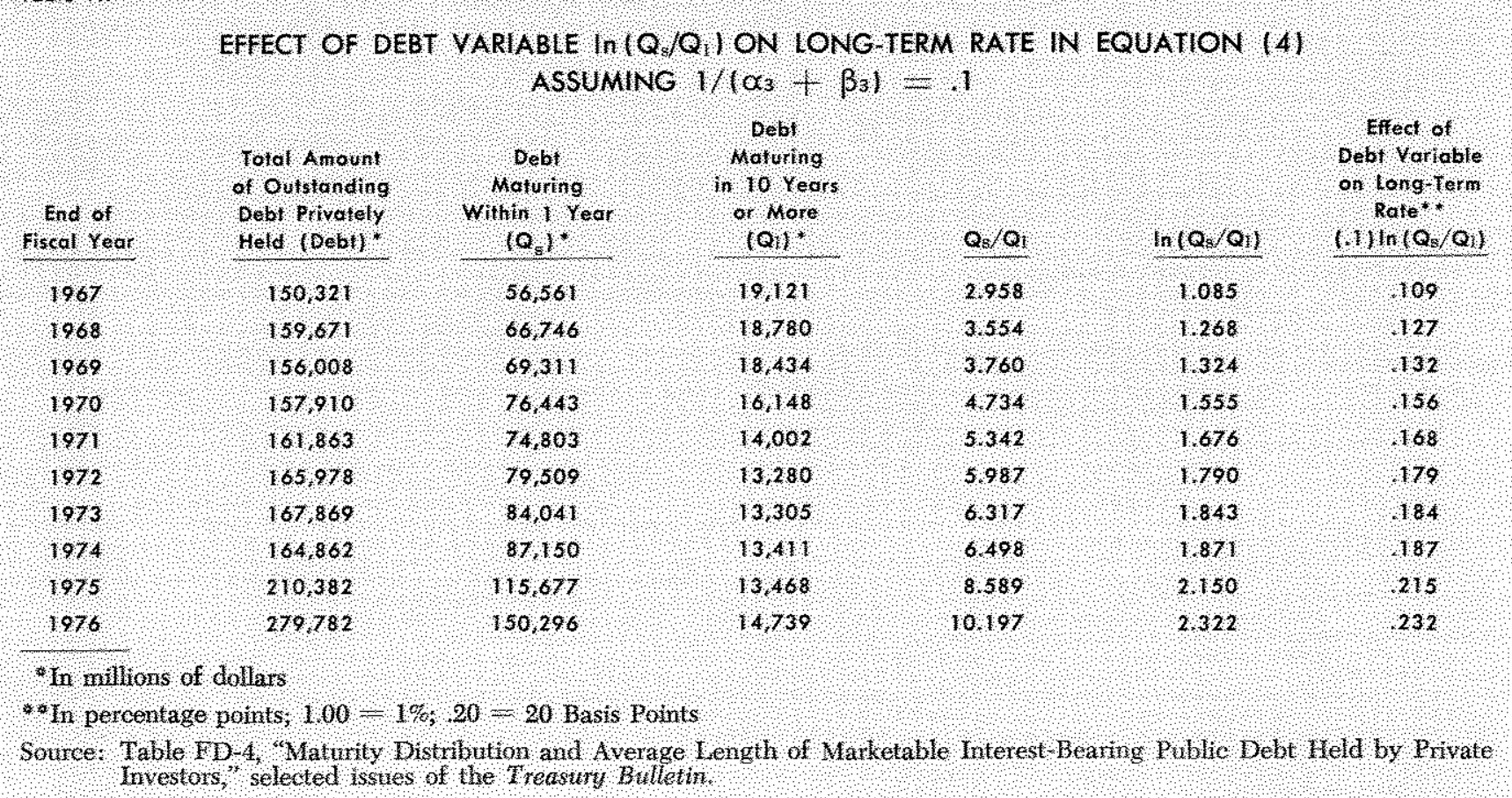




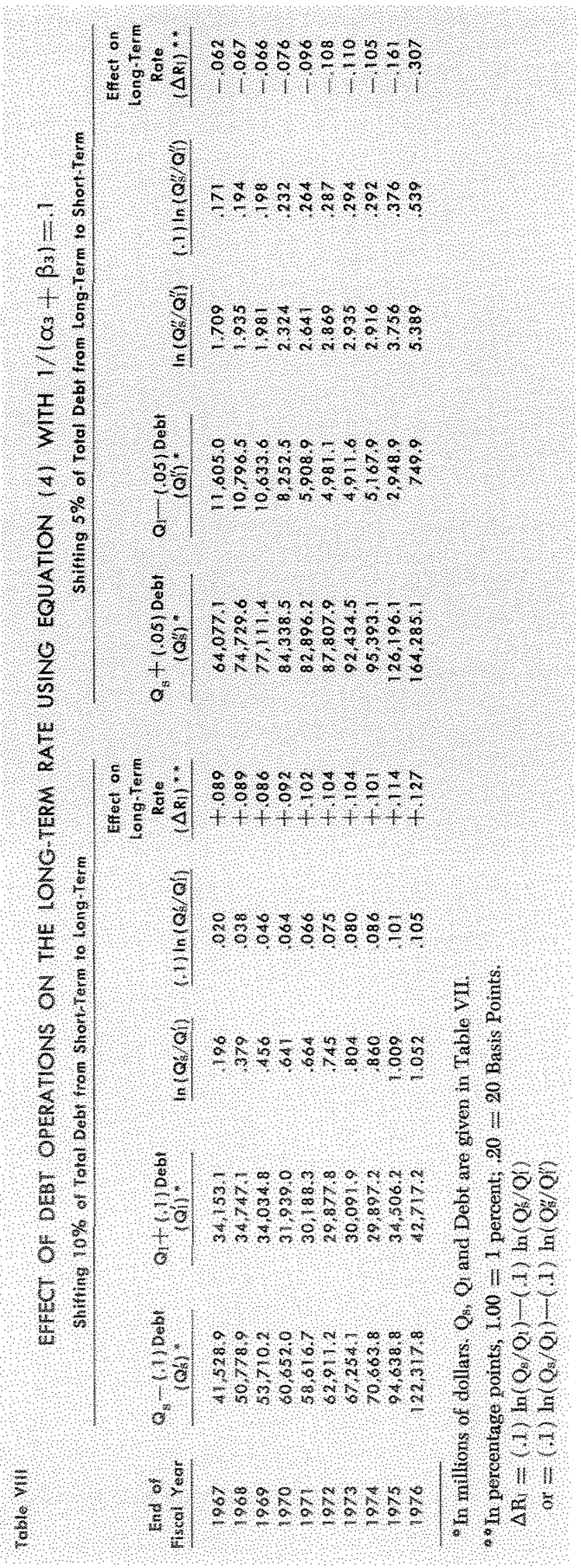

case. The exception is for fiscal year 1976, when the long-term rate would decrease by about 31 basis points under this debt-management operation. This change is still not very large, and is accounted for by the fact that shifting 5 percent of the debt from long. to short-term in fiscal 1976 reduces the amount of long-term debt outstanding to only $\$ 750$ million. It is to be expected from equation (4) that if the amount of long-term debt outstanding were virtually eliminated by a debt-management operation, the long-term rate would fall considerably more than would otherwise be the case.

From the examples given in Table VIII, we again find that, even using actual ratios of short- to longterm debt, the large elasticities of demand for Treasury securities imply that the debt variable has a relatively sraall impact on the long-term rate. Only massive changes in the maturity composition of the debt will have very large effects. ${ }^{30}$

\section{CONCLUSTONS}

Measures of the own price (and interest rate) elasticity of demand for Treasury securities, derived from data on Treasury subscription sales, indicate that the demands for both long- and short-term Govemment debt are very elastic. Market demand functions for long- and short-term debt were used to obtain a Modigliani-Sutch equation of the term structure of interest rates. The large interest rate elasticities of demand imply that the coefficients of the maturity composition of the debt in this equation are expected to be quite small. Based on these estimates, even large changes in the maturity composition of the debt will have little effect on long-term interest rates on Treasury securities. These results are consistent with, and help to explain, the empirical results found by Modigliani and Sutch and other researchers, and support the position that discretionary debt-management operations have little usefuness as a policy tool.

\footnotetext{
Whe above discussion implicitly assumes that the stock of debt of differing maturities can be taken as exogenons variables (see fontnote 27). This may not be an appropriate representation of the behavior of the Treasury. However; the introduction of the simultaneous detemination of the supply and demand for Govemnent debt, by introducing a debi-service minimization policy, prevents estimation of any maturity-composition effects using livis tem-structure framework (see Appentix).
}

Appendix follows on next page. 


\section{APIIDNIX}

This appendix considers the case of endogenous supplies of Govermment debt. There has been a great deal of discussion of Treasury policies which suggests that the goal of the Treasury, at teast thronghout the 1950s, was to manage the maturty stmcture of the debt so as to minimize the cost of the debt service. If this is the case, we can charactize the behavior of the Treasury by the following supply equations:

$\ln \left(\mathrm{Q}_{\mathrm{a}} / \mathrm{DEBT}\right)=y_{0}-\gamma_{1} \mathrm{R}_{\mathrm{s}}+\gamma_{2} \mathrm{R}_{1} \quad\left(\gamma_{i}>0\right)$

$\ln \left(\mathrm{Q}_{1} / \mathrm{DEBT}\right)=\delta_{0}+\delta_{1} \mathrm{R}_{\tilde{N}}-\delta_{2} \mathrm{R}_{1} \quad\left(\delta_{\mathrm{i}}>0\right)$

Equations (A.1) and (A.2) imply that as the long-term rate goes up or the short-tem rate goes down, the Treas.

1See U.S., Congress, Joint Ecomonic Committee, Employment, Growth, and Price Levels, Study Paper No. 19, Warren L. Smith, "Debt Mamagement in the United States," 86 th Cong., 2nd sess., 1960. In the late 1960 s the ability of the Treastry to pursue any policies with respect to the maturity structure of the Government debt was severely limited by legal restrictions on the maximum coupon which could be placed on new bonds. Since this compon was substantially below prevailing market rates for long-term issues, the Treasury was effectively prohibited from issuing new bonds. ury shortens the average maturity of the debt, and vicem versa for lengthening the maturity of the debt. By subtracting (A.2) from (A.1) we obtain:

$\ln \left(Q_{s} / \mathrm{DEBT}\right)-\ln \left(\mathrm{Q}_{1} / \mathrm{DEBT}\right)=\ln \left(\mathrm{Q}_{3} / \mathrm{Q}_{1}\right)=$

$\left(\gamma_{0}-\delta_{0}\right)-\left(\gamma_{1}+\delta_{1}\right) R_{s}+\left(\gamma_{2}+\delta_{2}\right) R_{1}$

When this is substituted into equation (3), the resulting solution for $\mathrm{R}_{3}$ is: ;

$$
\begin{aligned}
& R_{1}=\frac{k_{1}+\left(\alpha_{1}+\beta_{2}+\gamma_{1}+\delta_{1}\right) R_{5}+\left(\alpha_{2}+\beta_{2}\right) R_{5}}{\left(\gamma_{2}+\delta_{2}+\alpha_{3}+\beta_{3}\right)} \\
& \text { where } k_{0}=\left(\alpha_{0}-\beta_{0}-\gamma_{0}+\delta_{0}\right) \\
& \text { (A.4) }
\end{aligned}
$$

Equation (A.4) has a form similar to that of the estimated Modighani-Sutch equation, but implies that the maturitycomposition tems do not appear in the equation. Consequently, the introduction of the simultaneous detemination of the supply and demand for Govermment debt, as a result of a debt-service minimation policy, prevents estimation of any maturity-composition effects using this temstructure framework.

Ygnoring the terms in $Z_{s}$ and $Z_{1}$. 
FEDERAL RESERVE BANK OF ST. LOUIS

P. O. BOX 442

ST. LOUIS, MISSOURI 63166

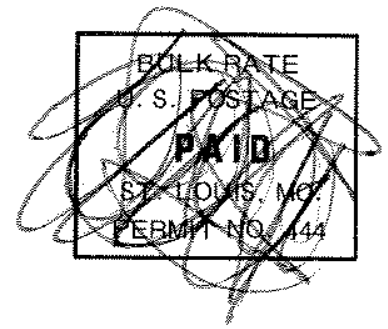

RETURN POSTAGE GUARANTEED 